\title{
WILDLIFE AND FOREST MANAGEMENT MEASURES SIGNIFICANTLY IMPACT RED DEER POPULATION DENSITY
}

\author{
MJERE U LOVSTVU I ŠUMARSTVU ZNAČAJNO UTJEČU \\ NA GUSTOĆU POPULACIJE JELENA OBIČNOG
}

\author{
Matija STERGAR ${ }^{1}$, Klemen JERINA²
}

\begin{abstract}
Summary
Red deer (Cervus elaphus L.) is in many parts of the world ecologically important and highly popular game species. Its population densities and environmental impacts largely depend on habitat suitability, which in turn is under strong influence of humans. Wildlife management intentionally improves habitat suitability, while forestry's impacts on red deer are mostly unintentional. In both disciplines the full extent of these impacts is poorly understood. To better understand habitat use and improve management of red deer, we studied the impacts of multiple environmental and historical factors, mostly anthropogenic, on red deer spatial distribution in Slovenia. We found that the probability of red deer presence and population density are higher close to locations of historic ( $>100$ years ago) red deer reintroduction sites and in large continuous forest complexes. The finding is important for forecasting future red deer distribution and population dynamics. Population density is also positively dependent on proximity to supplemental feeding sites, the proportion of spruce stands in pole-stage and the share of forest young growth, which is important for preventing unwanted impacts of red deer on forest. The approach used by this study and its results are also useful for improving habitat ranking of hunting grounds, which some countries use in wildlife management planning.
\end{abstract}

KEY WORDS: red deer, habitat suitability, population density, wildlife management, forest management, supplemental feeding, Slovenia

\section{INTRODUCTION}

\section{UVOD}

Red deer (Cervus elaphus L.) is in many areas of the world ecologically and economically one of the key wildlife species and as such directly and significantly impacts human welfare and ecosystems (Apollonio et al. 2010, Figgins and Holland 2012, Gude et al. 2012). For example, by foraging on plants, defecating, urinating and transporting nutrients, it affects the local availability of nutrients in soil and thus ecosystem productivity (Schoenecker et al. 2002, Mohr et al. 2005, Smit and Putman 2011); red deer is also an important zoochoric species (Malo and Suarez 1998, Oheimb et al. 2005, Iravani et al. 2011), and a key food source for large carnivores (Smietana and Klimek 1993, Hebblewhite et al. 2002, Jedrzejewski et al. 2002). Moreover, red deer is a

\footnotetext{
${ }^{1}$ Matija Stergar, uni. dipl. ing. for., Slovenia Forest Service, Večna pot 2, 1000 Ljubljana

${ }^{2}$ Prof. dr. sc. Klemen Jerina, Professor, Ph.D., University of Ljubljana, Biotehnical Faculty, Department of Forestry and Renewable Forest Resources, Večna pot 83, 1000 Ljubljana

Corresponding author: matijastergar@gmail.com
} 
highly popular game species (Apollonio et al. 2010, Csányi et al. 2014). On the other hand, it may cause severe damage in forestry (browsing, bark stripping and rubbing young trees), and agriculture (grazing on meadows and fields; Gill 1992, Reimoser and Gossow 1996, Verheyden et al. 2006, Mysterud et al. 2010, Marchiori et al. 2012).

The magnitude of red deer impacts on the environment and humans primarily depends on its local population density (Putman 1996, Palmer et al. 2007). The principal factor that determines population density is habitat suitability (Sinclair et al. 2005), which may be in numerous ways affected by humans, both intentionally and unintentionally. In wildlife management, for example, supplemental feeding and other measures are performed to improve environmental carrying capacity, which affects spatial distribution and fitness of red deer (Putman and Staines 2004, Rodriguez-Hidalgo et al. 2010, Jerina 2012). Forestry measures constantly transform forests and consequently (often unintentionally) affect their habitat suitability for red deer (Adamič 1991, Reimoser and Gossow 1996, Kramer et al. 2006, Kuijper et al. 2009). The full extent of anthropogenic factors is usually poorly understood (Weisberg and Bugmann 2003). Therefore it is difficult or almost impossible to properly address them in forest and wildlife management planning. To optimise and rationalise red deer management, it is important to know the impacts of a variety of factors, in particular of the anthropogenic kind, on habitat suitability.

Space use of red deer may be affected by a variety of natural and anthropogenic environmental as well as ,historical” factors (events/management in the past). Key factors include topography (altitude, exposure, slope; Debeljak et al. 2001, Zweifel-Schielly et al. 2009, Baasch et al. 2010, Stewart et al. 2010, Alves et al. 2014) and climate (temperature, precipitation, wind; Schmidt 1993, Conradt et al. 2000, Luccarini et al. 2006). Numerous studies have also demonstrated the impact of different anthropogenic factors: a) forest characteristics, in particular proportion of forest in the landscape (Biro et al. 2006, Zweifel-Schielly et al. 2009, Heurich et al. 2015), fragmentation (Licoppe 2006, Baasch et al. 2010, Allen et al. 2014) and internal forest structure (e.g. proportion of individual age classes, conifer/broadleaf ratio; Debeljak et al. 2001, Licoppe 2006, Borkowski and Ukalska 2008, Alves et al. 2014); b) supplemental feeding sites (Putman and Staines 2004, Luccarini et al. 2006, PerezGonzalez et al. 2010, Jerina 2012, Reinecke et al. 2014), fields and meadows (Biro et al. 2006, Godvik et al. 2009, Zweifel-Schielly et al. 2009, Perez-Barberia et al. 2013, Lande et al. 2014); c) disturbance factors such as roads and hiking trails (Baasch et al. 2010, Jerina 2012, Meisingset et al. 2013). Among the „historical” factors, present-day space use is probably most strongly affected by past management of red deer, in particular drastic interventions such as erad- ication or reintroduction of species (Apollonio et al. 2010, Scandura et al. 2014).

Habitat studies of wild ungulates including red deer can generally be divided into small-scale and large-scale studies. Small-scale studies are commonly conducted on small areas (less than one to several $10 \mathrm{~km}^{2}$ ) and are based on detailed spatial data such as telemetry and pellet group counting (e.g. Luccarini et al. 2006, Lovari et al. 2007, Borkowski and Ukalska 2008, Heinze et al. 2011, Alves et al. 2014). They typically include only few environmental factors with narrow gradients of values (because usually environment does not change drastically over small distances). Therefore they are more locally relevant and should not be extrapolated. On the other hand, large-scale (e.g. regional level) studies are based on rough indicators of population density (e.g. culling), typically referring to large (up to several 10 $\mathrm{km}^{2}$ ) administrative units (hunting grounds, municipalities; e.g. Mysterud et al. 2002, Merli and Meriggi 2006, Cowled et al. 2009). The limitation of such studies is that they cannot reliably analyse environmental factors which vary at a smaller spatial scale (e.g. internal forest structure). There is, however, an absence of studies combining the benefits of both approaches.

The purpose of this study was to analyse the impacts of environmental and historical factors on spatial distribution and local population density of red deer on extensive area but at a fine spatial resolution, thus combining the advantage of both approaches. With the aim to improve both red deer and forest management, we focused on habitat factors affected by both disciplines.

\section{STUDY AREA \\ PODRUČ́JE ISTRAŽIVANJA}

The study area comprises the entire Slovenia $\left(20,273 \mathrm{~km}^{2}\right.$; $45^{\circ} 25^{\prime}-46^{\circ} 53^{\prime} \mathrm{N}, 13^{\circ} 23^{\prime}-16^{\circ} 36^{\prime} \mathrm{E}$ ), which has very diverse geographical, climatic and landscape features. As such it is also a very diverse red deer habitat, which contributes to the robustness of the study. Average annual temperatures range from $0^{\circ} \mathrm{C}$ to $14^{\circ} \mathrm{C}$ and precipitation from $800 \mathrm{~mm}$ to $3300 \mathrm{~mm}$ (Ogrin 1996). Altitude ranges from sea level to $>2500 \mathrm{~m}$ high Alpine peaks; $59 \%$ of the land is covered in forest; forest cover varies locally from $<20 \%$ in predominantly agricultural and urban areas to $>90 \%$ in large massifs of Dinaric mountains and Pre-alps (Figure 1; Jakša 2012). Mixed forests are the most common forest type; however, the conifer/broadleaf ratio varies significantly. Common beech (Fagus sylvatica L.) and Norway spruce (Picea abies (L.) Karst.) are the most abundant tree species, representing $31 \%$ and $30 \%$ of the growing stock, respectively. They are followed by silver fir (Abies alba Mill.) with 7\% and sessile oak (Quercus petraea (Matt.) Liebl.) with 6\%; individual shares of other species are $<5 \%$. Majority of for- 


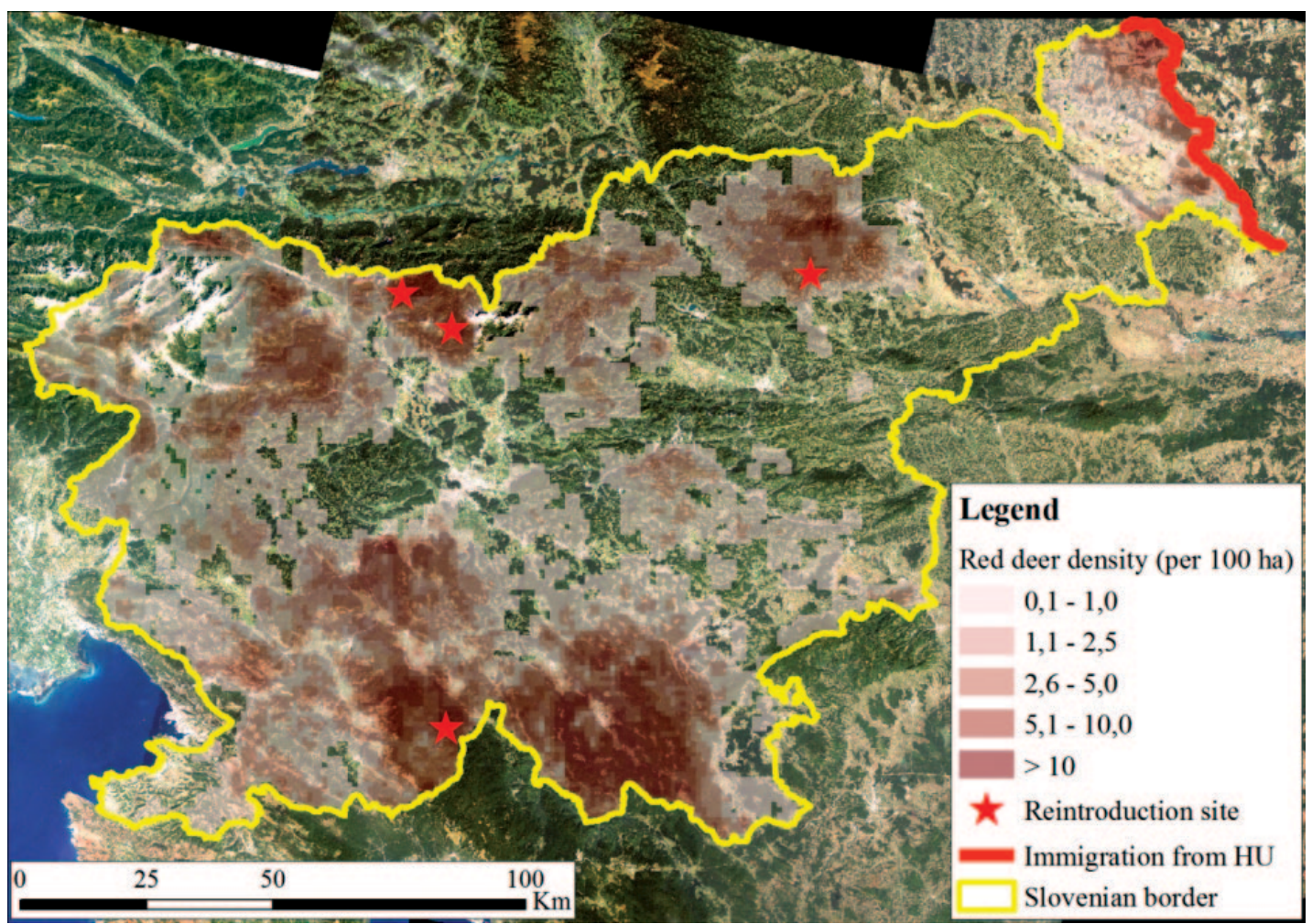

Figure 1: Satellite image of Slovenia showing red deer density, reintroduction sites and line where red deer started dispersing from Hungary. Slika 1: Satelitska snimka Slovenije s prikazom gustoće jelena običnog, mjesta reintrodukcije i linija s koje se jelen obični proširio iz Mađarske.

ests consist of small-scale heterogeneous stands (Jakša 2012). Large even-aged stands (several dozen ha) are rare and typically originate from intensive spruce planting after the World War II (Diaci 2006).

Red deer distribution range covers $60 \%$ of Slovenia, its local population densities range from minimal (occasional occurrences) to $>20$ individuals $/ \mathrm{km}^{2}$ (Stergar et al. 2012). In addition to habitat, present-day spatial distribution of red deer is affected by historical factors. In the second half of the $19^{\text {th }}$ century, after the Spring of Nations, red deer was hunted to extinction in Slovenia and in many other parts of the Austro-Hungarian monarchy. But soon after, at the turn of the $20^{\text {th }}$ century, it was reintroduced at three sites (Figure 1): Snežnik (S), Karavanke (N) and Pohorje (N-NE; Adamič et al. 2007). From these sites and later also form Hungary (NE) it started to expand and repopulate Slovenia. Even nowadays, more than 100 years after reintroductions, red deer is still spatially expanding (Stergar et al. 2009).

Aside from culling, one of the key red deer management measures is supplemental feeding, whose intensity varies strongly between hunting grounds. At hunting ground level $\left(\sim 50 \mathrm{~km}^{2}\right)$ the maximum permitted feeding station density is $1 / 5 \mathrm{~km}^{2}$ or $1 / 10 \mathrm{~km}^{2}$, but locally it can reach up to $3 / 1$ $\mathrm{km}^{2}$. Red deer is purposely fed throughout winter, but the same stations can be used for feeding of brown bear and wild boar, extending availability of supplemental food throughout the year. Red deer is typically fed a combination of feed: roughage (hay, grass silage) juicy feed (root crops, fruit), and concentrate fodders (maize, grain; Adamič and Jerina 2011, Jakša 2011).

\section{METHODS}

\section{METODE}

Preparation of data on local red deer population densities - Priprema podataka o lokalnim gustoćama populacija jelena običnog

Our study is based on data with a relatively fine spatial resolution $\left(1 \mathrm{~km}^{2}\right)$ considering the size of the area (the entire country). Estimates of local red deer population densities for all $1 \times 1$ kilometre raster cells in Slovenia were obtained combining two well established methods: pellet group counting (Neff 1968, Campbell et al. 2004) and culling density (Imperio et al. 2010, Ueno et al. 2014). The benefits of both methods were utilised: availability of culling density on large area (whole country) and precision of pellet group counting.

All Slovenian hunting grounds systematically record all culling data of ungulate game species with spatial precision of $1 \times 1 \mathrm{~km}$ (Virjent and Jerina 2004). Data on all culls in the period 2006-2011 (30 597 culled animals) was used for the analysis. Cull density in kilometre raster cells was used as the baseline indicator of local population density. 
Using a sample of 240 plots in $1201 \times 1$ kilometre cells scattered over a large portion of red deer range in Slovenia, we checked the relation between cull density and actual density calculated with pellet group counting. We built a generalised linear model that predicts actual local population density (based on pellet group counts) from different mortality causes (harvest, loss, traffic mortality) in different spatial windows $(1 \times 1 \mathrm{~km}, 3 \times 3 \mathrm{~km})$. Established predictive regression equations were extrapolated to the entire country (described in Stergar et al. (2012)).

\section{Preparation of data on environmental factors - Priprema podataka o okolišnim čimbenicima}

The study involved a broad range of environmental variables (Table 1) that could potentially (according to the results of previous studies) impact space use of red deer. The data on environmental variables were acquired from publicly available and our own databases.

Due to sex-specific dispersal, red deer spatially expands relatively slow and its expansion in Slovenia is not yet completed (Stergar et al. 2009). Population density at specific location may thus be affected by current habitat factors and management as well as by distance of this location from reintroduction site (and of habitat suitability in between). In addition to habitat variables, we therefore introduced the variable "cost distance", which for any location within the population area represents the „cost" (difficulty) of migration from reintroduction/immigration site. Since there are four reintroduction/immigration macro-sites, Slovenia was divided into four areas (following Jerina (2006a)). Since it is more difficult for red deer to disperse through more fragmented space (space with lower habitat suitability), the difficulty of migration through each quadrant was arbitrarily assigned an index inversely proportional to the percentage of forest in the quadrant. Quadrants containing human settlements were by default designated as absolute obstacles to migration. Cost distance map was calculated with the CostGrow algorithm implemented in the GIS package Idrisi 17.00.

Baseline values of all environmental variables and variable cost distance were prepared in $1-\mathrm{km}^{2}$ raster corresponding to the population density data. Actual values of variables used in the analysis were calculated for each cell as the average value of cell and eight neighbouring cells; each cell thus represents the value of the variable for a $3 \times 3 \mathrm{~km}$ area. This size corresponds to the average home range size of red deer in Slovenia (Jerina 2006a).

\section{Statistical analysis - Statistička analiza}

Dependence between environmental factors, cost distance (independent variables) and population density (dependent variable) was analysed at the level of $1 \times 1 \mathrm{~km}$ cells. Due to the specifics of the applied method for determining pop- ulation densities (see Stergar et al. (2012)) and the averaging of independent variables in the $3 \times 3 \mathrm{~km}$ grid, the data were spatially auto-correlated. Potential problems with spatial auto-correlation (Dormann et al. 2007) were avoided by systematically sampling only each central of the 9 neighbouring cells in the $3 \times 3 \mathrm{~km}$ grid. Of the 19746 quadrants entirely located within Slovenia, 2197 were used for subsequent analysis.

Previous studies (Johnson 1980, Mayor et al. 2009) showed that habitat use is a hierarchical process, occurring at multiple spatial and temporal scales (multi-order habitat use): the first order represents global range of species, the second order local species densities, the third order space use within home range, and the fourth order selection of microlocations for foraging and other activities. Our study separately examines the impacts of environmental factors on red deer space use of first and second order. In second-order analysis we included broad range of potentially relevant environmental variables, while in first-order analysis we omitted all variables that we assumed cannot impact the global range of the species (e.g. internal forest structure), and variables for which it is impossible to determine whether they are the cause or the consequence of red deer presence/absence (e.g. supplemental feeding).

First-order analysis involved all 2197 sampled cells, of which 1335 with red deer presence were used for second-order analysis. At both levels dependence between independent variables and the dependent variable was first checked with bivariate (Table 1) and then with multivariable analysis. At first order we used Point-biserial correlation (Tate 1954) and binary logistic regression (Hosmer et al. 2013) due to the binary dependent variable (red deer present/absent). At second order, where the dependent variable (red deer density) is continuous, we used Spearman correlation and generalised linear models (GLM) with gamma distribution of the dependent variable (Zuur et al. 2009), which corresponds to the distribution of red deer density.

All independent variables were first standardised. For both types of regression models we checked whether the relationships between the independent variables and the dependent variable were linear. The variable temperature was found to relate nonlinearly, thus square transformed temperature was additionally included in the model. To avoid multicollinearity, we: a) first calculated Spearman correlation for pairs of independent variables; if the absolute value of the correlation coefficient was $>0.6$, the variable with the assumed ecologically less meaningful impact on red deer presence/density was excluded, and b) additionally excluded the variables with variance inflation factor $>3$ (Zuur et al. 2009). After multicollinear variables were excluded, the final selection of variables was made for both types of models (Table 1). We calculated all possible models and ex- 
Table 1: Baseline selection of environmental variables, correlation between independent variables and dependent variable, and final selection of variables (after exclusion of multicollinear variables) for both model types.

Tablica 1: Polazišni izbor okolišnih varijabli, korelacija između nezavisnih varijabli i zavisne varijable te konačni izbor varijabli (nakon isključivanja multikolineralnih varijabli) za oba modela.

\begin{tabular}{|c|c|c|c|c|}
\hline $\begin{array}{l}\text { Abbreviation } \\
\text { of variable } \\
\text { Kratica } \\
\text { varijable }\end{array}$ & $\begin{array}{l}\text { Description } \\
\text { of variable } \\
\text { Opis } \\
\text { varijable }\end{array}$ & 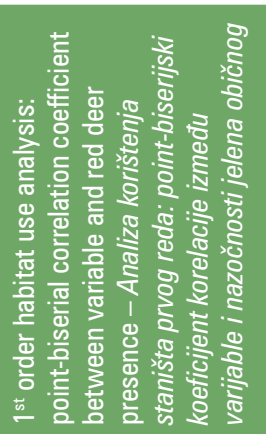 & 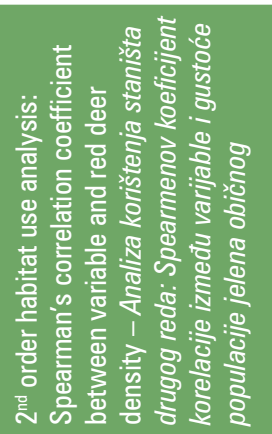 & 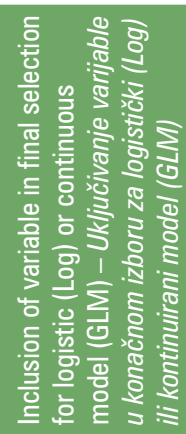 \\
\hline ALT & $\begin{array}{l}\text { Altitude } \\
\text { Nadmorska visina }\end{array}$ & 0.33 & 0.28 & / \\
\hline TEMP & $\begin{array}{l}\text { Average annual temperature } \\
\text { Prosječna godišnja temperatura zraka }\end{array}$ & -0.29 & -0.29 & Log, GLM \\
\hline PRECIP & $\begin{array}{l}\text { Average annual precipitation } \\
\text { Prosječna godišnja količina padalina }\end{array}$ & 0.34 & 0.23 & l \\
\hline SLOPE & $\begin{array}{l}\text { Slope } \\
\text { Nagib }\end{array}$ & 0.24 & 0.03 & GLM \\
\hline RADIAT & $\begin{array}{l}\text { Average annual sun radiation } \\
\text { Prosječno godišnje sunčevo zračenje }\end{array}$ & * & -0.08 & / \\
\hline FOREST & $\begin{array}{l}\text { Percentage of forests } \\
\text { Udio šuma }\end{array}$ & 0.49 & 0.40 & Log, GLM \\
\hline F_PATCH & $\begin{array}{l}\text { Size of the largest forest patch } \\
\text { Veličina najveće šumske plohe }\end{array}$ & 0.41 & 0.35 & Log, GLM \\
\hline F_EDGE & $\begin{array}{l}\text { Density of forest edge }\left(\mathrm{m} / \mathrm{km}^{2}\right) \\
\text { Gustoća ruba šume }\left(\mathrm{m} / \mathrm{km}^{2}\right)\end{array}$ & -0.19 & -0.39 & Log, GLM \\
\hline F_YOUNG & $\begin{array}{l}\text { Percentage of forest stands with young growth } \\
\text { Udio šumskih sastojina u fazi mladika }\end{array}$ & * & 0.23 & / \\
\hline F_SPRUCE & $\begin{array}{l}\text { Percentage of spruce (>90\%) pole stands } \\
\text { Udio smrekovih sastojina s više od } 90 \% \text { mladih sastojina }\end{array}$ & * & 0.25 & GLM \\
\hline F_MAST & $\begin{array}{l}\text { Percentage of broadleaves with } \mathrm{dbh}>30 \mathrm{~cm} \\
\text { Udio bjelogorice } s \text { prsnim promjerom }>30 \mathrm{~cm}\end{array}$ & * & 0.15 & GLM \\
\hline AGR_LAND & $\begin{array}{l}\text { Percentage of agricultural land } \\
\text { Udio poljoprivrednih površina }\end{array}$ & * & -0.35 & / \\
\hline FEED_DIST & $\begin{array}{l}\text { Distance to the nearest supplemental feeding station } \\
\text { Udaljenost do najbližeg hranilišta }\end{array}$ & * & -0.41 & GLM \\
\hline FEED_N & $\begin{array}{l}\text { Number of supplemental feeding stations within } 3 \times 3 \mathrm{~km} \text { area } \\
\text { Broj hranilišta na području } 3 \times 3 \mathrm{~km}\end{array}$ & * & 0.33 & / \\
\hline COST_DIST & $\begin{array}{l}\text { Cost distance to the reintroduction site } \\
\text { Troškovna udaljenosti do mjesta reintrodukcije }\end{array}$ & -0.49 & -0.54 & Log, GLM \\
\hline
\end{tabular}

*Variable not included in baseline selection in this analysis.

*Varijable koje nisu uključene u polazišnom izboru u ovoj analizi

plored the structure of all candidate models with $\triangle \mathrm{AIC}$ scores $\leq 2$ and used them for model averaging to obtain robust parameter estimates (Burnham and Anderson 2002). All statistical analyses were conducted with $R$ ver. 3.0.2.

\section{RESULTS}

REZULTATI

According to the Akaike information criterion, red deer presence/absence is best explained by two logistic regre- ssion models $(\triangle \mathrm{AIC} \leq 2)$. The models predict that the probability of red deer presence depends on share of forest (FOREST, positive correlation), cost distance (COST_DIST, negative correlation) and size of largest forest patch ( $\mathrm{F}_{-}$ PATCH, positive correlation); the second best model also includes density of forest edge (F_EDGE, negative correlation; Table 2).

According to the Akaike information criterion, local red deer densities are best explained by four models with $\triangle \mathrm{AIC} \leq 2$ (GLM) including following variables: distance to 
Table 2: Results of AIC weighed model of red deer presence (logistic regression). The variables are listed by descending order based on absolute values of standardised parameter estimates. The model correctly classifies $76 \%$ of all cases: $83 \%$ of positive (deer present) and $65 \%$ of negative (deer absent) cases.

Tablica 2: rezultati AIC ponderiranog modela nazočnosti jelena običnog (logistička regresija). Varijable su pobrojane silazno prema utjecaju na apsolutne vrijednosti standardiziranih procjena smjernih koeficijenata. Model ispravno klasificira 76\% svih slučajeva: 83\% slučajeva nazočnosti jelenske divljači i $65 \%$ slučajeva nenazočnosti jelenske divljači.

$\begin{array}{lcccc} & \text { Parameter estimate } & \text { Std. Error } & \text { Z-value } & \text { P-value } \\ \text { Procjena parametra } & \text { Standardna pogreška } & \text { Z-vrijednost } & <\text {-vrijednost } \\ \text { FOREST } & 0.88 & 0.06 & 13.80 & <0.001 \\ \text { COST_DIST } & -0.82 & 0.07 & 11.70 & <0.001 \\ \text { F_PATCH } & 0.57 & 0.07 & 8.12 & <0.001 \\ \text { F_EDGE } & -0.04 & 0.06 & 0.64 & 0.522\end{array}$

Table 3: Results of AIC weighed model of red deer population density (GLM). Variables are listed by descending impact based on absolute values of standardised estimates. Pearson's $r$ between actual and predicted values is 0.55 .

Tablica 3: Rezultati AIC ponderiranog modela gustoće populacije jelena običnog (GLM). Varijable su pobrojane silazno prema utjecaju standardiziranih procjena smjernih koeficijenata na apsolutne vrijednosti. Pearsonov r između stvarnih i predviđenih vrijednosti je 0.55.

\begin{tabular}{|c|c|c|c|c|}
\hline & $\begin{array}{l}\text { Parameter estimate } \\
\text { Procjena parametra }\end{array}$ & $\begin{array}{c}\text { Std. Error } \\
\text { Standardna pogreška }\end{array}$ & $\begin{array}{c}\text { Z-value } \\
\text { Z-vrijednost }\end{array}$ & $\begin{array}{c}\text { P-value } \\
\text { P-vrijednost }\end{array}$ \\
\hline FEED_DIST & -0.34 & 0.03 & 9.73 & $<0.001$ \\
\hline COST_DIST & -0.33 & 0.04 & 8.63 & $<0.001$ \\
\hline F_PATCH & 0.19 & 0.04 & 5.02 & $<0.001$ \\
\hline F_SPRUCE & 0.18 & 0.03 & 5.32 & $<0.001$ \\
\hline F_EDGE & -0.16 & 0.04 & 3.86 & $<0.001$ \\
\hline FOREST & 0.10 & 0.05 & 2.09 & 0.037 \\
\hline SLOPE & -0.05 & 0.05 & 0.91 & 0.361 \\
\hline F_MAST & 0.02 & 0.03 & 0.61 & 0.545 \\
\hline TEMP* & 0.48 & 0.21 & 2.36 & 0.018 \\
\hline TEMP $\times$ TEMP* & -0.50 & 0.21 & 2.43 & 0.015 \\
\hline
\end{tabular}

*For the variable temperature (TEMP) the model also included the squared transformation of the variable (TEMP $\times$ TEMP). Positive estimate of variable and negative estimate of squared variable mean that red deer density initially increases with increasing temperature and then starts decreasing. Direct comparison of impact of temperature with other variables is not possible.

*Za varijablu temperatura (TEMP) model je uključivao i kvadriranje varijable (TEMP $\times$ TEMP). Pozitivna procjena varijable i negativna procjena kvadrata varijable znače da se gustoća jelena običnog prvotno povećava s povećanjem temperature, nakon čega slijedi pad. Direktna usporedba utjecaja temperature s drugim varijablama nije moguća.

nearest supplemental feeding site (FEED_DIST, negative correlation), cost distance (COST_DIST, negative correlation), size of largest forest patch (F_PATCH, positive correlation), share of spruce dominated pole-stage (F_SPRUCE, positive correlation), density of forest edge (F_EDGE, negative correlation), proportion of forest (FOREST, positive correlation), and ambient temperature (TEMP, first ascending then descending). Two of the four models also involve slope (SLOPE, negative correlation) and share of mast-producing broadleaves (F_MAST, positive correlation; Table 3).

\section{DISCUSSION AND CONCLUSIONS RASPRAVA I ZAKLJUČCI}

Our study demonstrates that red deer local population densities are under strong impact of present-day wildlife management measures (e.g. the impact of supplemental feeding) as well as forestry measures (e.g. proportion of stands of certain age-class and tree species composition). Both local densities and, to an even greater extent, presence or absence of red deer, are also impacted by historical circumstances: past red deer management (eradication and reintroduction) and past land use, which is reflected in present-day forest cover and fragmentation of forest.

Recognising the impact of historical factors helps us understand past dynamics of red deer populations and predict potential future spatial distribution of the species. Dispersal from reintroduction and immigration sites still impacts red deer spatial distribution in Slovenia despite having started 100 years ago. We can therefore assume that the locations of reintroduction sites have been the main factor determining the course of dispersal and repopulation of the country by red deer, following its reintroduction. This factor will remain important in the future, as spatial expansion of species has not yet been completed (Stergar et al. 2009). The importance of share of forest cover and its fragmentation (for habitat suitability) shows that past land use, in particular the abandonment of agriculture and spontaneous afforestation of agricultural land in the $20^{\text {th }}$ century, significantly contributed to the red deer population dynamics (Adamič and Jerina 2011). The situation is very similar to the major- 
ity of European countries: the imminent extinction of red deer was followed by reintroduction or immigration in the $19^{\text {th }}$ and $20^{\text {th }}$ century, which led to gradual population increases. In the subsequent decades the abandonment of agriculture further contributed to increasing population trend of red deer and other ungulates around Europe (Apollonio et al. 2010, Scandura et al. 2014).

Aside from past human activities, local red deer population densities are significantly influenced by our present-day interventions, in particular wildlife and forest management measures. Unlike past activities which we cannot influence, present-day management measures can be adjusted at will to achieve the desired impacts on red deer and, consequently, on the environment. The biggest limitation thereof is the often poor knowledge of the strength and complexity of the impacts these measures have on red deer, rendering it difficult to properly target them (Putman 1996, Weisberg and Bugmann 2003).

The inherent complexity of direct and indirect effects of supplemental feeding on red deer is a typical example. Hunters across Europe feed red deer with the aim to attract it and increase its fitness and trophy value. Researchers and forest managers, on the other hand, consider the measure highly controversial due to the potentially undesired impacts on forest (Putman and Staines 2004, Milner et al. 2014). Feeding undoubtedly impacts space use of red deer; numerous studies showed that red deer intensely use supplemental feeding stations and their surroundings and that supplementary feeding reduces annual home ranges of red deer (Luccarini et al. 2006, Perez-Gonzalez et al. 2010, Ferretti and Mattioli 2012, Jerina 2012, Reinecke et al. 2014). The results of our study indicate that the impact of feeding stations is even much broader: they increase densities at the meso-population level as well, thereby augmenting the environmental impacts of red deer. Probably the most common negative impact of feeding is over-browsing and bark stripping in the vicinity of feeding stations, which has been shown by several studies (Ueckermann 1983, Schmidt and Gossow 1991, Nahlik 1995). Red deer which visits feeding stations almost never consume exclusively supplementary feed, but also forages natural vegetation in the vicinity (up to several 100 meters) of the feeding stations to balance their dietary needs (Adamič 1990, Schmitz 1990).

Supplemental feeding is often practised to increase animals' trophy value and fitness, but the results are often the opposite from expectations of hunters and wildlife managers. Whereas few studies have shown positive impacts of feeding on red deer fitness and others have not detected any impacts, numerous studies even demonstrated negative impact on red deer body mass and in some cases even increased mortality as a consequence of supplemental feeding (for review see Milner et al. (2014)). High density of red deer at supplemental feeding stations can strongly increases intraspecific competition for food. Especially females and younger animals visiting feeding stations are often displaced by stags, which undermines the fitness of these social groups (Wiersema 1974, Schmidt 1992, Seivwright 1996, Putman and Staines 2004). Another cause of decreased fitness and higher mortality is facilitated transmission of disease and parasites among individuals due to their high concentrations at supplemental feeding sites (Hines et al. 2007, Cross et al. 2010, Scurlock and Edwards 2010).

Whereas wildlife management measures are targeted at improving red deer habitat, forest management measures are predominantly aimed at wood production; their impacts on red deer, and indirectly on forest, are often completely overlooked. By changing the age-class ratio and tree species composition, forestry impacts key components of red deer habitat suitability: food abundance and presence of security and snow interception cover (Adamič 1990, Reimoser and Gossow 1996, Kramer et al. 2006, Kuijper et al. 2009, Heinze et al. 2011).

Similar as in past studies, bivariate correlation in our study indicates a positive impact of forest regeneration abundance on red deer density. In accordance with the optimal bite selection theory, which states that diet selection is affected by quality as well as abundance of food (Iain and Herbert 2008), red deer often concentrates in forest regeneration gaps (Reimoser and Gossow 1996, Kuijper et al. 2009). However here, unlike in the case of concentrations at feeding stations, the effect on regeneration capacity of forest is in general favourable. In larger regeneration gaps (and in sylvicultural systems with larger proportion of regeneration areas) red deer is practically saturated with food, therefore it cannot compromise successful recruitment of young growth (Storms et al. 2006). At the same time regeneration gaps attract red deer from parts of forest with more dispersed regeneration which is more exposed to browsing (Stergar 2005, Jerina 2008). In general, for successful mitigation of negative impacts of ungulates on forest, wildlife management as well as forest management measures have to be adjusted accordingly: sufficient presence and abundance of forest regeneration and selection of a sylvicultural system that provides herbivores with more food and consequently reduces browsing.

In addition to forest regeneration gaps, red deer also selects spruce-dominated pole stands as shown in our analysis, however the effect on forest in this case is completely opposite. Spruce pole stands are very appealing, but at the same time a poor-quality habitat, i.e. an ecological trap (Adamič 1990, Reimoser and Gossow 1996). Snow interception and favourable thermal cover make spruce-dominated pole stands popular wintering areas for red deer, but since the availability of food in such stands is very low, red 
deer are forced in extreme winters to consume bark of young spruce, which is often the only available food (Gill 1992, Völk 1999, Ueda et al. 2002). Stands planted on abandoned grassland and pastures, especially those on humid sites where spruce is particularly susceptible to disease, are especially vulnerable. When supplemental feeding sites are located in the vicinity of such stands, the damaging impacts accumulate, which may result in completely destroyed stands (Čampa 1986). Increased culling of red deer is commonly considered the first and only measure to prevent or reduce bark stripping (Putman 1989). Studies however indicate it is often ineffective, as red deer can cause massive bark stripping even at very low densities (Völk 1999, Verheyden et al. 2006). It is more effective to avoid creating such spruce plantations in the first place (Vospernik 2006) or to systematically reduce their favourable cover conditions for red deer by carrying out intensive thinning, which reduces interception of snow and increases its ground thickness. At the same time, more radiation increases bark roughness, which reduces its attraction and accelerates radial growth, and consequently reduces the time such stands are exposed to back stripping (Vospernik 2006, Jerina et al. 2008, Mansson and Jarnemo 2013).

Indirect impacts of wildlife and forest management measures on red deer habitat use within their home range have been confirmed by several studies. Our study is one of the first to demonstrate the impacts of wildlife and forest management measures also at the population level, which suggests that the impacts of the studied factors are much broader and more complex than typically assumed. $\mathrm{Ne}$ glecting these impacts is therefore particularly damaging, for both red deer and the environment. Wildlife and forest management measures, which impact red deer, also indirectly affect the forest. Measures in both disciplines must therefore be planned in a coordinated manner (Gerhardt et al. 2013). When planning placement of supplemental feeding stations, the distribution of forest stands should be taken into account. The most vulnerable stands - regenerated areas and spruce-dominated pole stands - must be avoided. Feeding can negatively impact red deer fitness and is also a relatively expensive measure (Putman and Staines 2004, Milner et al. 2014). The intensity of feeding should therefore probably be reduced in certain areas. Instead, improvement of more natural resources for wild ungulates can be used as in middle European forestry practise (Weis 1997, Prien 1997). These measures can be implemented through making remises for wild ungulates on deforested land inside, or around forest stands (open strips, brackets, abandoned pastures and meadows etc.). In some parts of Slovenia there is a distinct lack of young growth and regeneration is dispersed, which leads to browsing problems (Jerina 2008); more young growth in large regeneration gaps would mitigate the problem. Pure spruce stands on non-native growing sites are susceptible not only to bark stripping but also to bark beetle outbreaks, fungi and windbreak (Diaci 2006). In Slovenia, intensive planting of spruce is a thing of the past, but in some other European countries the practice remains widespread and should be revised due to the negative impacts associated with red deer.

The results of studies such as ours can be useful directly in wildlife management planning, for example in habitat ranking of hunting grounds. Some European countries, including Croatia, use habitat ranking of hunting grounds for planning of hunting quotas, although the practice is in other countries generally being replaced by more modern methods of adaptive management. Habitat ranking (determining the expected habitat suitability for each species in the hunting grounds) is based on expert knowledge of the species and its habitat preferences (Apollonio et al. 2010, Morellet et al. 2011). Our study, on the other hand, quantitatively evaluated the impact of individual environmental factors on red deer habitat suitability, which could be used for the habitat ranking of given hunting ground. Since the environmental factors were studied at country level, their local effects can deviate from our estimates, which can therefore only be considered as average approximations to reality. In this sense the results of our study underline a shortcoming of habitat ranking: the method assumes that expert knowledge can always and everywhere be applied to reliably evaluate habitat suitability and target densities of red deer or other wild animals. However, this is difficult even with modern analysis of large sets of empirical data.

\section{ACKNOWLEDGMENTS ZAHVALA}

We thank to Miha Krofel for improving the English, to Sebastijan R. Maček for translation into English and to Vedran Sljepčević for translation into Croatian.

\section{REFERENCES LITERATURA}

- Adamič, M., 1990: Prehranske značilnosti kot element načrtovanja varstva, gojitve in lova parkljaste divjadi s poudarkom na jelenjadi (Cervus elaphus L.), Strokovna in znanstvena dela št. 105, VTOZD za gozdarstvo in Inštitut za gozdno in lesno gospodarstvo, 203 p., Ljubljana.

- Adamič, M., 1991: The influence of forestry on winter feeding and spacing strategies of red deer in southern Slovenia, Yugoslavia. In: Global trends in wildlife management. B. Bobek, K. Perzanowski, and W. Regelin (eds.). Trans. 18th IUGB Congres, Krakow 1987. Swiat Press. Krakow-Warzawa, 331-334.

- Adamič, M., P. Dovč, J. Frank, 2007: Varstvena genetika jelenjadi, Univerza v Ljubljani, Biotehniška fakulteta, Ljubljana.

- Adamič, M., K. Jerina, 2011: Ungulates and their management in Slovenia, European Ungulates and their Management in the 21st Century, Cambridge University Press, 507-526, New York. 
- Allen, A. M., J. Mansson, A. Jarnemo, N. Bunnefeld, 2014: The impacts of landscape structure on the winter movements and habitat selection of female red deer, Eur J Wildlife Res, 60: 411421.

- Alves, J., A. A. da Silva, A. Soares, C. Fonseca, 2014: Spatial and temporal habitat use and selection by red deer: The use of direct and indirect methods, Mamm Biol, 79: 338-348.

- Apollonio, M., R. Andersen, R. J. Putman, 2010: European Ungulates and their Management in the 21st Century, Cambridbe University Press, 604 p., Edinburgh.

- Baasch, D. M., J. W. Fischer, S. E. Hygnstrom, K. C. VerCauteren, A. J. Tyre, J. J. Millspaugh, J. W. Merchant, J. D. Volesky, 2010: Resource Selection by Elk in an Agro-Forested Landscape of Northwestern Nebraska, Environ Manage, 46: 725-737.

- Biro, Z., L. Szemethy, K. Katona, M. Heltai, Z. Peto, 2006: Seasonal distribution of red deer (Cervus elaphus) in a forest-agriculture habitat in Hungary, Mammalia, 70: 70-75.

- Borkowski, J., J. Ukalska, 2008: Winter habitat use by red and roe deer in pine-dominated forest, For Ecol Manage, 255: 468475.

- Burnham, K. P., D. R. Anderson, 2002: Model Selection and Multimodel Inference - A Practical Information-Theoretic Approach, Springer-Verlag, 488 p., New York.

- Campbell, D., G. M. Swanson, J. Sales, 2004: Comparing the precision and cost-effectiveness of faecal pellet group count methods, J Appl Ecol, 41: 1185-1196.

- Conradt, L., T. H. Clutton-Brock, F. E. Guinness, 2000: Sex differences in weather sensitivity can cause habitat segregation: red deer as an example, Anim Behav, 59: 1049-1060.

- Cowled, B. D., F. Giannini, S. D. Beckett, A. Woolnough, S. Barry, L. Randall, G. Garner, 2009: Feral pigs: predicting future distributions, Wildlife Res, 36: 242-251.

- Cross, P. C., D. M. Heisey, B. M. Scurlock, W. H. Edwards, M. R. Ebinger, A. Brennan, 2010: Mapping Brucellosis Increases Relative to Elk Density Using Hierarchical Bayesian Models, PLoS One, 5.

- Csányi, S., J. Carranza, B. Pokorny, R. Putman, M. Ryan, 2014: Valuing ungulates in Europe, Behaviour and Management of European Ungulates, Whittles Publishing, 304, Dunbeath.

- Čampa, L., 1986: Poškodbe mlajših smrekovih monokultur po divjadi na Pohorju ter izdelava metodologije za obnovo prizadetih sestojev, Inštitut za gozdno in lesno gospodarstvo, 124 p., Ljubljana.

- Debeljak, M., S. Dzeroski, K. Jerina, A. Kobler, M. Adamic, 2001: Habitat suitability modelling for red deer (Cervus elaphus L.) in South-central Slovenia with classification trees, Ecol Model, 138: 321-330.

- Diaci, J., 2006: Gojenje gozdov: pragozdovi, sestoji, zvrsti, načrtovanje, izbrana poglavja, Univerzitetni učbenik, Univerza v Ljubljani, Oddelek za gozdarstvo in obnovljive gozdne vire, 348 p., Ljubljana.

- Dormann, C. F., J. M. McPherson, M. B. Araujo, R. Bivand, J. Bolliger, G. Carl, R. G. Davies, A. Hirzel, W. Jetz, W. D. Kissling, I. Kuhn, R. Ohlemuller, P. R. Peres-Neto, B. Reineking, B. Schroder, F. M. Schurr, R. Wilson, 2007: Methods to account for spatial autocorrelation in the analysis of species distributional data: a review, Ecography, 30: 609-628.

- Ferretti, F., S. Mattioli, 2012: The Mesola red deer: present numbers and conservation perspectives, Hystrix, 23: 35-43.
- Figgins, G., P. Holland, 2012: Red deer in New Zealand: Game animal, economic resource or environmental pest?, N Z Geogr, 68: 36-48.

- Gerhardt, P., J. M. Arnold, K. Hackländer, E. Hochbichler, 2013: Determinants of deer impact in European forests - A systematic literature analysis, For Ecol Manage, 310: 173-186.

- Gill, R. M. A., 1992: A review of damage by mammals in north temperate forests 1: Deer, Forestry, 65: 145-169.

- Godvik, I. M. R., L. E. Loe, J. O. Vik, V. Veiberg, R. Langvatn, A. Mysterud, 2009: Temporal scales, trade-offs, and functional responses in red deer habitat selection, Ecology, 90: 699-710.

- Gude, J. A., J. A. Cunningham, J. T. Herbert, T. Baumeister, 2012: Deer and elk hunter recruitment, retention, and participation trends in Montana, J Wildl Manage, 76: 471-479.

- Hebblewhite, M., D. H. Pletscher, P. C. Paquet, 2002: Elk population dynamics in areas with and without predation by recolonizing wolves in Banff National Park, Alberta, Can J Zool, 80: 789-799.

- Heinze, E., S. Boch, M. Fischer, D. Hessenmöller, B. Klenk, J. Müller, D. Prati, E.-D. Schulze, C. Seele, S. Socher, S. Halle, 2011: Habitat use of large ungulates in northeastern Germany in relation to forest management, For Ecol Manage, 261: 288-296.

- Heurich, M., T. T. G. Brand, M. Y. Kaandorp, P. Šustr, J. Müller, B. Reineking, 2015: Country, Cover or Protection: What Shapes the Distribution of Red Deer and Roe Deer in the Bohemian Forest Ecosystem?, PLoS One, 10: 1-17.

- Hines, A. M., V. O. Ezenwa, P. Cross, J. D. Rogerson, 2007: Effects of supplemental feeding on gastrointestinal parasite infection in elk (Cervus elaphus): Preliminary observations, Vet Parasitol, 148: 350-355.

- Hosmer, D. W., S. Lemeshow, R. X. Sturdivant, 2013: Applied Logistic Regression, 3rd Edition, Applied Logistic Regression, 3rd Edition, Blackwell Science Publ, 1-500, Oxford.

- Iain, J. G., H. T. P. Herbert, 2008: The Ecology of Browsing and Grazing, Springer Berlin Heidelberg, p., Berlin.

- Imperio, S., M. Ferrante, A. Grignetti, G. Santini, S. Focardi, 2010: Investigating population dynamics in ungulates: Do hunting statistics make up a good index of population abundance?, Wildlife Biol, 16: 205-214.

- Iravani, M., M. Schutz, P. J. Edwards, A. C. Risch, C. Scheidegger, H. H. Wagner, 2011: Seed dispersal in red deer (Cervus elaphus L.) dung and its potential importance for vegetation dynamics in subalpine grasslands, Basic Appl Ecol, 12: 505-515.

- Jakša, 2011: Navodila za usmerjanje razvoja populacij divjadi v Sloveniji, Zavod za gozdove Slovenije, 34 p., Ljubljana.

- Jakša, 2012: Vektorska karta gozdnih sestojev v Sloveniji, Zavod za gozdove Slovenije, Ljubljana.

- Jedrzejewski, W., K. Schmidt, J. Theuerkauf, B. Jedrzejewska, N. Selva, K. Zub, L. Szymura, 2002: Kill rates and predation by wolves on ungulate populations in Bialowieza Primeval Forest (Poland), Ecology, 83: 1341-1356.

- Jerina, K., 2006a: Prostorska razporeditev, območja aktivnosti in telesna masa jelenjadi (Cervus elaphus L.) glede na okoljske dejavnike, Doktorska disertacija Univerza v Ljubljani, Biotehniška fakulteta, Ljubljana.

- Jerina, K., 2006b: Vplivi okoljskih dejavnikov na prostorsko razporeditev divjega prašiča (Sus scrofa L.) v Sloveniji, Zbornik gozdarstva in lesarstva, 81: 3-20. 
- Jerina, K., 2008: Velika rastlinojeda divjad in razvojna dinamika gozdnih ekosistemov: proučevanje vplivov izbranih okoljskih in populacijskih parametrov ter gozdno-gojitvenih sistemov na zmožnosti naravne obnove: zaključno poročilo o rezultatih opravljenega raziskovalnega dela na projektu v okviru ciljnega raziskovalnega projekta (CRP) „Konkurenčnost Slovenije 20062013“, Biotehniška fakulteta, Oddelek za gozdarstvo in obnovljive gozdne vire, 27 p., Ljubljana.

- Jerina, K., 2012: Roads and supplemental feeding affect homerange size of Slovenian red deer more than natural factors, J Mammal, 93: 1139-1148.

- Jerina, K., M. Dajčman, M. Adamič, 2008: Red deer (Cervus elaphus) bark stripping on spruce with regard to spatial distribution of supplemental feeding places, Zbornik gozdarstva in lesarstva, 86: 33-43.

- Johnson, D. H., 1980: The comparison of usage and availability measurements for evaluating resource preference, Ecology, 61: 65-71.

- Kramer, K., G. Bruinderink, H. H. T. Prins, 2006: Spatial interactions between ungulate herbivory and forest management, For Ecol Manage, 226: 238-247.

- Kuijper, D. P. J., J. P. G. M. Cromsigt, M. Churski, B. Adam, B. Jedrzejewska, W. Jedrzejewski, 2009: Do ungulates preferentially feed in forest gaps in European temperate forest?, For Ecol Manage, 258: 1528-1535.

- Lande, U. S., L. E. Loe, O. J. Skjaerli, E. L. Meisingset, A. Mysterud, 2014: The effect of agricultural land use practice on habitat selection of red deer, Eur J Wildlife Res, 60: 69-76.

- Licoppe, A. M., 2006: The diurnal habitat used by red deer (Cervus elaphus L.) in the Haute Ardenne, Eur J Wildlife Res, 52: 164-170.

- Lovari, S., P. Cuccus, A. Murgia, C. Murgia, F. Soi, G. Plantamura, 2007: Space use, habitat selection and browsing effects of red deer in Sardinia, Ital J Zool, 74: 179-189.

- Luccarini, S., L. Mauri, S. Ciuti, P. Lamberti, M. Apollonio, 2006: Red deer (Cervus elaphus) spatial use in the Italian Alps: home range patterns, seasonal migrations, and effects of snow and winter feeding, Ethol Ecol Evol, 18: 127-145.

- Malo, J. E., F. Suarez, 1998: The dispersal of a dry-fruited shrub by red deer in a Mediterranean ecosystem, Ecography, 21: 204211.

- Mansson, J., A. Jarnemo, 2013: Bark-stripping on Norway spruce by red deer in Sweden: level of damage and relation to tree characteristics, Scand J Forest Res, 28: 117-125.

- Marchiori, E., E. Sturaro, M. Ramanzin, 2012: Wild red deer (Cervus elaphus L.) grazing may seriously reduce forage production in mountain meadows, Ital J Anim Sci, 11.

- Mayor, S. J., D. C. Schneider, J. A. Schaefer, S. P. Mahoney, 2009: Habitat selection at multiple scales, Ecoscience, 16: 238-247.

- Meisingset, E. L., L. E. Loe, O. Brekkum, B. Van Moorter, A. Mysterud, 2013: Red deer habitat selection and movements in relation to roads, J Wildl Manage, 77: 181-191.

- Merli, E., A. Meriggi, 2006: Using harvest data to predict habitat-population relationship of the wild boar Sus scrofa in Northern Italy, Acta Theriol, 51: 383-394.

- Milner, J. M., F. M. Van Beest, K. T. Schmidt, R. K. Brook, T. Storaas, 2014: To feed or not to feed? Evidence of the intended and unintended effects of feeding wild ungulates, J Wildl Manage, 78: 1322-1334.
- Mohr, D., L. W. Cohnstaedt, W. Topp, 2005: Wild boar and red deer affect soil nutrients and soil biota in steep oak stands of the Eifel, Soil Biol Biochem, 37: 693-700.

- Morellet, N., F. Klein, E. Solberg, R. Andersen, 2011: The census and management of populations of ungulates in Europe, Ungulate Management in Europe - Problems and Practices, Cambridge University Press, 106-143, Nex York.

- Mysterud, A., H. Askilsrud, L. E. Loe, V. Veiberg, 2010: Spatial patterns of accumulated browsing and its relevance for management of red deer Cervus elaphus, Wildlife Biol, 16: 162-172.

- Mysterud, A., R. Langvatn, N. G. Yoccoz, N. C. Stenseth, 2002: Large-scale habitat variability, delayed density effects and red deer populations in Norway, J Anim Ecol, 71: 569-580.

- Nahlik, A., 1995: Browsing pressure caused by red deer and moufflon under various population densities in different forest ecosystems of Hungary; effects of supplementary winter feeding, Symposium on Ungulates in Temperate Forest Ecosystems, 23-27 April 1995, Wageningen.

- Neff, D. J., 1968: The Pellet-Group Count Technique for Big Game Trend, Census, and Distribution: A Review, J Wildl Manage, 32: 597-614.

- Ogrin, D., 1996: Podnebni tipi v Sloveniji. The climate types in Slovenia, Geografski vestnik, 68: 39-56.

- Oheimb, v. G., M. Schmidt, W. U. Kriebitzsch, H. Ellenberg, 2005: Dispersal of vascular plants by game in northern Germany. Part II: Red deer (Cervus elaphus), Eur J For Res, 124: 55 65.

- Palmer, S. C. F., J. E. Broadhead, I. Ross, D. E. Smith, 2007: Longterm habitat use and browsing by deer in a Caledonian pinewood, For Ecol Manage, 242: 273-280.

- Perez-Barberia, F. J., R. J. Hooper, I. J. Gordon, 2013: Long-term density-dependent changes in habitat selection in red deer (Cervus elaphus), Oecologia, 173: 837-847.

- Perez-Gonzalez, J., A. M. Barbosa, J. Carranza, J. Torres-Porras, 2010: Relative Effect of Food Supplementation and Natural Resources on Female Red Deer Distribution in a Mediterranean Ecosystem, J Wildl Manage, 74: 1701-1708.

- Prien, S., 1997: Interierte Maßnahmen zur Einschränkung der Wildschäden im Walde, Wildschäden im Wald: Ökologische Grundlagen und integrierte Schutzmaßnahmen. 1. Auflage, Blackwell Wissenschafts-Verlag, 159-222, Berlin, Wien.

- Putman, R. J., 1989: Introduction: mammals as Pests, Mammals as pests, Chapman and Hall, 1-20, London, New York.

- Putman, R. J., 1996: Ungulates in temperate forest ecosystems: Perspectives and recommendations for future research, For Ecol Manage, 88: 205-214.

- Putman, R. J., B. W. Staines, 2004: Supplementary winter feeding of wild red deer Cervus elaphus in Europe and North America: justifications, feeding practice and effectiveness, Mammal Rev, 34: 285-306.

- Reimoser, F., H. Gossow, 1996: Impact of ungulates on forest vegetation and its dependence on the silvicultural system, For Ecol Manage, 88: 107-119.

- Reinecke, H., L. Leinen, I. Thissen, M. Meissner, S. Herzog, S. Schutz, C. Kiffner, 2014: Home range size estimates of red deer in Germany: environmental, individual and methodological correlates, Eur J Wildlife Res, 60: 237-247.

- Rodriguez-Hidalgo, P., C. Gortazar, F. S. Tortosa, C. RodriguezVigal, Y. Fierro, J. Vicente, 2010: Effects of density, climate, and 
supplementary forage on body mass and pregnancy rates of female red deer in Spain, Oecologia, 164: 389-398.

- Scandura, M., M. Apollonio, N. Šprem, 2014: Reintroductions as a management tool for European ungulates Behaviour and Management of European Ungulates, Whittles Publishing, 4677, Dunbeath.

- Schmidt, K., 1993: Winter ecology of nonmigratory Alpine red deer, Oecologia, 95: 226-233.

- Schmidt, K. T., 1992: Uber den Einfluss von Futterung und Jagd auf das Raum-Zeit-Verhalten von Rotwild, Z Jagdwiss, 38: 88100 .

- Schmidt, K. T., H. Gossow, 1991: Winter ecology of alpine red deer with and without supplemental feeding: management implications, Proceeding of XXth Congress of the International Union of Game Biologists, 1991, 180-185.

- Schmitz, O. J., 1990: Management implications of foraging theory - evaluating deer supplemental feeding, J Wildl Manage, 54: 522-532.

- Schoenecker, K. A., F. J. Singer, R. S. C. Menezes, L. C. Zeigenfuss, D. Binkley, 2002: Sustainability of vegetation communities grazed by elk in Rocky Mountain National Park, Report, 187204, Fort Collins, CO.

- Scurlock, B. M., W. H. Edwards, 2010: Status of brucellosis in free-ranging elk and bison in Wyoming, J Wildl Dis, 46: 442449.

- Seivwright, L. J., 1996: The influence of supplementary winter feeding on the social behaviour of red deer (Cervus elaphus), BSc (Hons) Thesis, University of St Andrews, Fife, Scotland.

- Sinclair, A. R. E., J. M. Fryxell, G. Caughley, 2005: Wildlife Ecology, Conservation and Management, 2nd Edition, Blackwell Publishing, 488 p., Malden.

- Smietana, W., A. Klimek, 1993: Diet of wolves in the Bieszczady mountains, Poland, Acta Theriol, 38: 245-251.

- Smit, C., R. Putman, 2011: Large herbivores as 'environmental engineers', Ungulate management in Europe, Cambridge University Press, 260-283, New York.

- Stergar, M., 2005: Objedenost mladja drevesnih vrst v odvisnosti od zgradbe sestoja, Univerza v Ljubljani, BF, Oddelek za gozdarstvo, Ljubljana.

- Stergar, M., D. Borkovič, J. Hiršelj, I. Kavčič, M. Krofel, M. Mrakič, R. Troha, U. Videmšek, B. Vrčon, K. Jerina, 2012: Ugotavljanje gostot prostoživečih parkljarjev s kombinirano metodo štetja kupčkov iztrebkov in podatkov o odvzemu = Estimation of wild ungulate densities with a combined method of pellet group counting and removal data, Biotehniška fakulteta, Oddelek za gozdarstvo in obnovljive gozdne vire, 18 p., Ljubljana.

- Stergar, M., M. Jonozovič, K. Jerina, 2009: Območja razširjenosti in relativne gostote avtohtonih vrst parkljarjev v Sloveniji, Gozdarski vestnik, 67: 367-380.
- Stewart, K. M., R. T. Bowyer, J. G. Kie, M. A. Hurley, 2010: Spatial Distributions of Mule Deer and North American Elk: Resource Partitioning in a Sage-Steppe Environment, Am Midl Nat, 163: 400-412.

- Storms, D., S. Said, H. Fritz, J. L. Hamann, C. Saint-Andrieux, F. Klein, 2006: Influence of hurricane Lothar on red and roe deer winter diets in the Northern Vosges, France, For Ecol Manage, 237: 164-169.

- Tate, R. F., 1954: Correlation Between a Discrete and a Continuous Variable - Point-Biserial Correlation, Ann Math Stat, 25: 603-607.

- Ueckermann, E., 1983: Die Auswirkung verschiedener Futterkomponenten auf den Schälumfang des Rotwildes, Z Jagdwiss, 29: 31-47.

- Ueda, H., S. Takatsuki, Y. Takahashi, 2002: Bark stripping of hinoki cypress by sika deer in relation to snow cover and food availability on Mt Takahara, central Japan, Ecol Res, 17: 545551.

- Ueno, M., E. J. Solberg, H. Iijima, C. M. Rolandsen, L. E. Gangsei, 2014: Performance of hunting statistics as spatiotemporal density indices of moose (Alces alces) in Norway, Ecosphere, 5: $1-20$.

- Verheyden, H., P. Ballon, V. Bernard, C. Saint-Andrieux, 2006: Variations in bark-stripping by red deer Cervus elaphus across Europe, Mammal Rev, 36: 217-234.

- Virjent, Š., K. Jerina, 2004: Osrednji slovenski register velike lovne divjadi in velikih zveri v sklopu novega lovsko-informacijskega sistema, Lovec, 86: 280-281.

- Völk, F. H., 1999: Bedeutung von Waldstruktur und Rotwildhege für die Schälhäufigkeit in den alpinen Bundesländern Österreichs, Z Jagdwiss, 45: 1-16.

- Vospernik, S., 2006: Probability of bark stripping damage by red deer (Cervus elaphus) in Austria, Silva Fenn, 40: 589-601.

- Weis, G. B., 1997: Anlage und Pflege von Wildäsungsflächen. Nimrod-Verlag, 320 p.,Oldenburg,

- Weisberg, P. J., H. Bugmann, 2003: Forest dynamics and ungulate herbivory: from leaf to landscape, For Ecol Manage, 181: $1-12$.

- Wiersema, G. J., 1974: Observations on the supplementary winter feeding of red deer on an estate in the central highlands of Scotland, MSc Thesis, University of Wageningen, Wageningen.

- Zuur, A., E. N. Ieno, N. Walker, A. A. Saveliev, G. M. Smith, 2009: Mixed Effects Models and Extensions in Ecology with R, Springer Science \& Business Media, 574 p., New York.

- Zweifel-Schielly, B., M. Kreuzer, K. C. Ewald, W. Suter, 2009: Habitat selection by an Alpine ungulate: the significance of forage characteristics varies with scale and season, Ecography, 32: 103-113.

\section{Sažetak}

Jelen obični (Cervus elaphus L.) je u mnogim dijelovima svijeta važna ekološka vrsta i popularna divljač, te kao takva ima značajan izravan utjecaj na čovjeka. Istovremeno može imati štetne posljedice na okolišs, posebice na šumarstvo. Težina ovih posljedica ovisi o gustoći populacija jelena običnog, što zauzvrat u značajnom stupnju ovisi o kvaliteti staništa i prijašnjem upravljanju ovom vrstom. Oba čimbenika snažno odražavaju ljudske utjecaje. Ovo istraživanje proučava utjecaje određenih okolišnih i povijesnih čimbenika, posebice onih antropogenih, na raširenost i lokalne gustoće populacija jelena običnog. 
Područje istraživanja je Slovenija, zemljopisno, klimatski i krajobrazno izuzetno raznovrsna država. Jelen obični je u povijesti istrijebljen i reintroduciran prije 100 godina na nekoliko mjesta, a također je i spontano imigrirao iz Mađarske (Slika 1). Danas je proširen na 60\% površine države, ali nije još dosegao sva pogodna staništa zbog sporog širenja.

Analiza je obuhvatila nezavisne varijable širokog raspona okolišnih varijabli i varijable „troškovna udaljenost”, koja prikazuje „težinu” disperzije jelena običnog od mjesta reintrodukcije, odnosno imigracije. Procjene lokalnih gustoća jelena običnog (zavisna varijabla) su dobivene pomoću dvije metode: podaci o izvršenim odstrjelnim kvotama i metodom brojanja izmeta. Vrijednosti varijabli su pripremljene na relativno finoj prostornoj rezoluciji (imajući na umu površinu cijelog područja) od $1 \mathrm{~km}^{2}$. U skladu s teorijom o višestrukom izboru staništa, zavisnost jelena običnog o okolišu je analizirana na dvije razine: 1) globalni doseg jelena običnog (nazočnost/nenazočnost) i 2) gustoće lokalnih populacija unutar područja raširenosti. Na obje razine je provedena bivarijatna (korelacija) i multivarijatna (regresija) analiza.

Nazočnost jelena običnog je najvjerojatnija u blizini mjesta reintrodukcije, odnosno imigracije, što ističe važnost varijable „troškovna udaljenost”, te u velikim šumskim kompleksima, što ukazuje na pozitivan utjecaj udjela šume i veličinu šumske plohe te negativan utjecaj gustoće ruba šume (Tablica 1, Tablica 2). Ove varijable također utječu na gustoću populacije, koja raste s padom udaljenosti od hranilišta i pozitivno je vezana s udjelom sastojina u kojima dominira obična smreka. Korelacija također ukazuje na pozitivnu ovisnost s udjelom mladih sastojina (Tablica 1, Tablica 3).

Troškovna udaljenost od mjesta reintrodukcije te udio i kontinuitet šume prikazuje ljudske intervencije u povijesti (nekadašnje upravljanje jelenom običnim i korištenje prostora od strane čovjeka). Poznavanje utjecaja ovih čimbenika na jelena običnog je stoga važno za razumijevanje prošlosti i predviđanje buduće dinamike populacije. Stanište jelena običnog u Sloveniji još uvijek nije u potpunosti nastanjeno i širenje se nastavlja. Stoga se očekuje kontinuirano širenje jelena običnog, imajući na umu da brzina ovisi o načinima upravljanja prostorom. Stanje je slično i u većini drugih europskih zemalja.

Još je važnije poznavati utjecaje mjera u današnjem lovstvu i šumarstvu koje, mogu biti prilagođene s ciljem postizanja željenih utjecaja. Neke ustaljene prakse upravljanja često ostvaruju utjecaje suprotne željenima,i u budućnosti bi trebale biti ponovno razmatrane. U budućnosti bi više pozornosti trebalo posvetiti izboru mjesta na kojem bi se postavila hranilišta za jelensku divljač, a na nekim područjima bi se intenzitet prihranjivanja jelenske divljači trebao reducirati. Udio mladih stabala u šumama Slovenije je prenizak; stoga bi ili trebalo proširiti područja obnove šumskih sastojina ili osnovati krmne površine za divljač (remize). Upravljanje odnosima između šume i divljači zahtjeva suradnju djelatnika u lovstvu i djelatnika u šumarstvu.

Metoda primijenjena u našem istraživanju također bi mogla biti korištena za poboljšanje bonitiranja lovišta za jelensku divljač, jer su procjene utjecaja pojedinih okolišnih čimbenika na kvalitetu staništa jelena običnog temeljene na kvantitativnoj analizi.

KLJUČNE RIJEČI: jelen obični, kvaliteta staništa, gustoća populacije, lovstvo, šumarstvo, hranidba, Slovenija 